\title{
Spiritual Health as Experienced by Muslim Adults in Iran: A Qualitative Content Analysis
}

\author{
Azita Jaberi (iD ${ }^{1}$, Marzieh Momennasab (iD ${ }^{2,}{ }^{,}$, MohammadAli Cheraghi ${ }^{3}$, Shahrzad Yektatalab (iD ${ }^{2}$ and \\ Abbas Ebadi ${ }^{4,5}$ \\ Community Based Psychiatric Care Research Center, Shiraz University of Medical Sciences, Shiraz, Iran \\ ${ }^{2}$ Department of Nursing, School of Nursing and Midwifery, Shiraz University of Medical Sciences, Shiraz, Iran \\ ${ }^{3}$ School of Nursing and Midwifery, Tehran University of Medical Sciences, Tehran, Iran \\ ${ }^{4}$ Behavioral Sciences Research Center, Life Style Institute, Baqiyatallah University of Medical Sciences, Tehran, Iran \\ ${ }^{5}$ Nursing Faculty, Baqiyatallah University of Medical Sciences, Tehran, Iran \\ "Corresponding author: Department of Nursing, School of Nursing and Midwifery, Shiraz University of Medical Sciences, Shiraz, Iran. Email: mnasab48@yahoo.com
}

Received 2019 January 05; Revised 2019 July 08; Accepted 2019 July 13.

\begin{abstract}
Background: Spiritual health has attracted wide attention in health-related and nursing sciences. However, most research on this complex and ambiguous concept has been conducted from the Judeo-Christian philosophical worldview, and the Muslim community that comprises a large population of the world, and particularly the Iranian population, has not been investigated.

Objectives: The present study aimed to explore the experiences of Iranian Muslim adults regarding spiritual health.

Methods: This qualitative content analysis was conducted among 14 participants. Semi-structured interviews were used for data collection, and Granheim and Lundman (2004) method was used for qualitative content analysis. The results were categorized into six major themes.

Results: The six major themes extracted for spiritual health included harmonious reciprocal connectedness, moderation, spiritual striving, transcendence, purpose seeking and wisdom thinking, and faith. These characteristics were reciprocally interconnected and intertwined. It should be noted that some of the extracted attributes were quite new.

Conclusions: Considering the cultural and philosophical foundations of different communities, assessment of spiritual health in different societies would reveal novel and innovative aspects of this concept. Paying attention to these aspects is essential in the health promotion.
\end{abstract}

Keywords: Spiritual Health, Content Analysis, Faith, Transcendence

\section{Background}

Health is a general concept that includes physical, social, cultural, emotional, and spiritual dimensions (1). According to Osman and Russell, health sciences specialists consider the inclusion of spiritual dimension in the concept of health to be an important dimension of individual and social life (2). The World Health Organization (WHO) has also considered spiritual aspect in ensuring human healthcare nearly a quarter century ago (3). Despite extensive studies on spiritual health in the elderly (4), teenagers (5), children (6), and adults with chronic or terminal diseases and palliative care $(7,8)$, few studies have evaluated this concept in healthy adults $(9,10)$.

Examining spiritual health in various developmental phases is important because spiritual health takes various dimensions in developmental phases and in crises, and it develops with vicissitudes (11-13). Based on spiritual devel- opmental theories $(11,14)$, it can be claimed that spiritual health in children, adolescents, and the elderly is different from that in adults $(6,15)$. In Iran, adults comprise more than $65 \%$ of the population (16). Due to the fact that adults are the productive part of a community (17), assessing health aspects including the spiritual dimension in this population would be significantly important. Nonetheless, most studies in this area have been conducted in special populations, such as cancer survivors, cardiac patients, the elderly, etc. $(18,19)$.

Generally, many nurses in clinical settings are faced with a dimension of human experience that is beyond physical or mental issues. In this dimension, well-being and distress are related to the spirit and connection to something ultimate (20). Therefore, maintaining and improving spiritual health as well as physical health is certainly the responsibility of nurses as members of the 
health team $(21,22)$. Despite remarkable and growing attention and profound contributions, it is still believed that the concept is vague and complex and no consensus has been achieved in this regard (23). This ambiguity could be attributed to the use of alternative concepts or phrases like spirituality and spiritual well-being, various definitions presented based on different philosophical worldviews, and the fact that perceptions of the concept are different in diverse cultural contexts (24-28). Therefore, more investigations explaining this topic in different cultural contexts seem to be essential.

In Islamic teachings, spiritual dimension has been considered to be an important part of human existence (2934). However, the majority of studies performed in this area are related to Christianity (35-37), and few efforts have been made to define spiritual health from the perspective of Islam (38). Despite the large population of Muslims in the world and in Iran (with Muslims comprising more than $90 \%$ of the population)(39-41), a limited number of studies have been conducted in this domain, making it necessary to investigate this concept in the context of Iran.

Because of the abstraction and complexity of spiritual health, its theological overlapping with phrases and words such as psyche, soul, and spirituality (42-45), its complexity over lifetime from childhood to old ages, and its dependence on social and religious contexts, qualitative research would be necessary in order to explain this concept and its dimensions. In fact, because quantitative research, without the support of qualitative data, would keep rational and logical data hidden, the results of qualitative studies can uncover participants' deep insights and help clarify and explain the findings (46). On the other hand, to achieve a comprehensive understanding, the meanings experienced by participants have to be determined within the context of a particular field. Therefore, an accurate, comprehensive, and multi-faceted picture of spiritual health could be recreated by taking multiple images from different views (47).

\section{Objectives}

The present study aims to explore the experience of Iranian Muslim adults regarding spiritual health.

\section{Methods}

Semi-structured interviews with 14 participants was used for data collection, and for data analysis, a combination of manifest and latent content analyses was used. Manifest content analysis focuses only on the apparent text, while latent content analysis focuses on the underlying meaning of the text.
The study participants were selected through the purposive sampling method with maximum variation. In doing so, the researchers tried to select adults with diverse sociodemographic characteristics. Additionally, some other participants were recruited using the snowball sampling method. The inclusion criteria were being aged 18 - 60 years old according to the WHO definition, having the ability to provide rich information about spiritual health, not suffering from incurable diseases, being able to speak and understand Persian, and being Muslim. The participants were selected from adults of different age groups, genders, educational levels, and occupations. It should be mentioned that the participants were asked whether they were Muslim at the beginning of the interview.

The study setting included two large shopping centers, banks, Shiraz University of Medical Sciences, and the Center for the Retired. After finding the key informants and determining their willingness, interviews were conducted over nine months. None of the participants was excluded during the study. However, interviews were replicated in two cases. After providing the participants with verbal explanation about the study and taking their verbal and written consents, the interviews were carried out according to ethical considerations.

The data were collected through semi-structured interviews. The interviews were started with a general question: "What does health mean to you?". In order to prompt discussions, the following questions were asked: "In your opinion, what is the meaning of spiritual health?" and "What are the dimensions of spiritual health?". Based on the participants' viewpoints, further questions began to emerge. Accordingly, the related terms, such as faith, connectedness, and peacefulness, underwent further explorations using probing questions. After all, the interviews were recorded and transcribed. The interviews lasted for 48 minutes on average. After 14 interviews, data saturation was discussed with the research team. The team agreed that the data saturation point was achieved and no major discrepancy was observed during the interviews. Then, some of the transcribed interviews were returned to the participants to declare their opinions about modifying or completing the codes and themes.

The study data were analyzed based on the steps proposed by Granheim and Lundman (2004): (1) transcribing and reviewing the interviews to understand the whole text, (2) extracting the units of meaning and categorizing them into condensed units of meaning, (3) summarizing and classifying the condensed meaning units and selecting an appropriate label for them, (4) arranging the condensed meaning units based on similarities and differences in subcategories, and (5) choosing an appropriate title that could cover the resulting subcategories (48). The research team 
members' discussions continued until the disagreements were resolved. Finally, consensus about the obtained codings and themes was established by the research team.

Credibility, dependability or auditability, fitness and transferability (external validity), and confirmability, which are the criteria of scientific rigor in qualitative research presented by Guba and Lincoln (49), were considered in this study. Data verification by the participants (member check), prolonged engagement with the participants, searching for contrasting evidence, researcher's and team members' credibility, external check, and triangulation methods were taken into account for credibility. In addition, giving feedback to the participants, data verification by the participants, describing the concepts in contrast to spiritual health, and accurate memo-writing about the process of transforming primary data to categories provided dependability or auditability. Besides, sampling by maximum variation along with purposive sampling and deep and rich data helped achieve transferability. Finally, thick and in-depth descriptions of the study data and trend and audit trial were employed in order to confirm the data.

\subsection{Ethical Considerations}

This study was approved by the Ethics Committee of Shiraz University of Medical Sciences (code: 93-7216). The study participants were fully aware of the study objectives and methodology. Obtaining process informed consent after introducing the research and the researcher, maintaining the participants' anonymity and data confidentiality, and the ability to leave the study at any stage were the other ethical considerations.

\section{Results}

According to the study objectives and design, 12 adult participants were interviewed. The participants' demographic characteristics are presented in Table 1.

\subsection{The Participants' Viewpoints About Spiritual Health}

Spiritual health was discussed from the participants' perspective, revealing six main themes and 17 subthemes. The extracted themes and subthemes are shown in Table 2.

\subsection{Harmonious Reciprocal Connectedness}

Reciprocal connectedness was one of the major themes of the concept of spiritual health manifested in the relationship with God, self, others, and nature. The first and most prominent connection stated by the participants was relationship with God. Iranians start their daily activities by relationship with God, seek for God's help in dealing with crises and problems, trust in and rely on Him, and consider this connection for their comfort and peace. In this respect, one of the participants mentioned:

"It (spiritual health) means someone who has a special connection with God. It seems to me that the word 'spiritual' basically refers to the relationship you have with God" (P1).

Another aspect of relationship was connectedness with oneself. Many participants believed that every human being has a conscience that helps him in different situations. Such a connection with one's conscience and inner self helps individuals achieve spiritual health. In Islamic teachings, thinking and reasoning is the basis of every kind of transcendence. In this respect, the participants pointed out the importance of thinking, attitude, and introspection in creation and promotion of spiritual health. One of the participants stated:

"We have programmed our minds just to see the beauties. All this comes back to my attitude. I mean that change in humans (spiritual health) is the result of change in their attitudes" (P11).

Connectedness with others was another component of spiritual relationships. The participants mentioned connection with family and friends as a part of this relationship and considered it to be a source of comfort. Communicating with neighbors and family members, especially parents, which has been emphasized in the teachings of Islam, was so important and honored by the participants that, in some situations, they were willing to set aside some of their hobbies: "I feel good when I'm with my family" (P12). Another participant also said: "(Sometimes) my friends planned a weekend trip, but I said no to them because I'd rather make my parents happy" (P9).

Relationship with nature and environment was also mentioned by several participants. This relationship is also known to "make prospects and souls hum" according to Islamic teachings. In this regard, the participants maintained: "I'm always here at work. Every time I feel so stressed that I can't stand it anymore, the first thing I do, well, our home is somewhere with many trees and a beautiful nature, I just go and sit there, and I only listen to the nature." (P7) "About animals ... because they are created by God ... we are responsible for them ... All creatures together are like a chain that, if properly arranged, becomes a whole and causes all to enjoy together. That's spiritual health, I think" (P6).

\subsection{Moderation}

Moderation was one of the themes attained for the first time in the studies conducted in this area. The participants believed that this attribute of spiritual health could be seen in personal and social behaviors. Not having onedimensional behaviors and neglecting some aspects of existence, having existence and health aspects with no con- 


\begin{tabular}{|c|c|c|c|c|c|}
\hline No. & Age, $y$ & Gender & Education Level & \multicolumn{2}{|r|}{ Marital Status } \\
\hline P1 & 58 & Male & Diploma & Office worker & Married \\
\hline P2 & 51 & Female & Primary school education & College manservant & Divorced \\
\hline P3 & 46 & Male & Primary school education & Shepherd & Married \\
\hline P5 & 28 & Male & M.Sc. degree & University student & Single \\
\hline P6 & 43 & Female & B.Sc. degree & Hair stylist & Married \\
\hline P7 & 23 & Female & Diploma & Shopkeeper & Single \\
\hline P8 & 21 & Female & B.Sc. degree & University student & Single \\
\hline P9 & 47 & Male & M.Sc. degree & Librarian & Single \\
\hline P10 & 26 & Male & M.Sc. degree & University student & Single \\
\hline P11 & 60 & Male & Diploma & Retired & Married \\
\hline P12 & 56 & Male & Diploma & Shopkeeper & Married \\
\hline P13 & 22 & Male & B.Sc. degree & University student & Single \\
\hline P14 & 24 & Female & B.Sc. degree & Not employed & Single \\
\hline \multicolumn{2}{|c|}{ Themes } & \multicolumn{2}{|c|}{ Subthemes } & \multicolumn{2}{|l|}{ Meaning Unit } \\
\hline \multicolumn{2}{|c|}{$\begin{array}{l}\text { Harmonious reciprocal } \\
\text { connectedness }\end{array}$} & \multicolumn{2}{|c|}{$\begin{array}{l}\text { Connectedness with God; Connectedness with self; } \\
\text { Connectedness with others; Connectedness with nature; } \\
\text { Harmonious and reciprocal relationships }\end{array}$} & \multicolumn{2}{|c|}{$\begin{array}{l}\text { "(Spiritual health) means someone who has a special connection with } \\
\text { God"; "Change in humans (spiritual health) is the result of change in } \\
\text { their attitudes"; “I feel good when I'm with my family"; "I just go and sit } \\
\text { there, and I only listen to the nature" }\end{array}$} \\
\hline \multicolumn{2}{|c|}{ Moderation } & \multicolumn{2}{|c|}{$\begin{array}{l}\text { Moderation in personal issues; Moderation in social } \\
\text { issues }\end{array}$} & \multicolumn{2}{|c|}{$\begin{array}{l}\text { "Everything would be in its right place, it's the balance"; "Some } \\
\text { extremist groups are religious, but ... well, this is not belief" }\end{array}$} \\
\hline \multicolumn{2}{|c|}{ Spiritual striving } & \multicolumn{2}{|c|}{$\begin{array}{l}\text { Abstainer; Spiritual thinking and contemplation; } \\
\text { Self-reflection }\end{array}$} & \multicolumn{2}{|c|}{$\begin{array}{l}\text { "It's like an inner struggle how much you could be resistant"; } \\
\text { "Experience, problems, events, or threats that make you think" }\end{array}$} \\
\hline \multicolumn{2}{|c|}{ Transcendence } & \multicolumn{2}{|c|}{$\begin{array}{l}\text { In the "becoming" pathway; Spiritual development; } \\
\text { Spiritual flourishment }\end{array}$} & \multicolumn{2}{|c|}{$\begin{array}{l}\text { "Something has happened to me, please save me and I'll be your servant. } \\
\text { You know"; "He (a person who is spiritually healthy) is beneficial to } \\
\text { other humans ... He puts aside his selfishness and creates something ... } \\
\text { He sacrifices himself" }\end{array}$} \\
\hline \multicolumn{2}{|c|}{$\begin{array}{l}\text { Purpose seeking and } \\
\text { wisdom thinking }\end{array}$} & \multicolumn{2}{|c|}{ Becoming purposeful; Considering divine wisdom } & \multicolumn{2}{|c|}{$\begin{array}{l}\text { "I believe, from the perspective of a Muslim, ... a man came to this world } \\
\text { from somewhere, he has something to do and somewhere to go. His } \\
\text { destination and goal are not here"; "A man who believes in God won't be } \\
\text { afraid of anything ... of difficulties. He will consider everything as divine } \\
\text { wisdom" }\end{array}$} \\
\hline \multicolumn{2}{|c|}{ Faith } & Intern & I faith & $\begin{array}{l}\text { "Religion is a way to achieve spir } \\
\text { belief system places at the top o } \\
\text { which screens everything and d }\end{array}$ & $\begin{array}{l}\text { ieve"; "A value and } \\
\text { e acting as a filter ... } \\
\text { good and what is bad" }\end{array}$ \\
\hline
\end{tabular}

flicts with each other, moderation in personal and social lifestyles (behaviors, speech, grooming, etc.), social commitment, and respect for others' rights were the aspects of moderation. In this regard, the participants maintained:

"(Spiritual health is the) regularity that comes to life, that everything would be in its right place, it's the balance ..." (P3). "We say that the only thing Islam has mentioned about ethics is moderation" (P10).

In this regard, the participants expressed that individuals who had not complied with moderation in their thoughts and behaviors were actually "caricatures", with some parts of their existential aspects having grown more and some others less. In this respect, one of the participants said:

"A lot of people are religious, some extremist groups are religious, but ... well, this is not belief. Many people have these types of beliefs, which are actually dangerous"(P11).

\subsection{Spiritual Striving}

This theme was also one of the concepts revealed in spiritual health studies for the first time. According to the 
participants, spiritual thinking, contemplation, and reflection along with spiritual striving and abstinence were necessary for the inner journey to acquire spiritual health. They strongly believed that after reaching a degree of spiritual health, it would not be easy to maintain and protect spiritual health unless by hard struggle and resistance against internal and external forces.

"(Spiritual health means) ... being steadfast ... when you are going on a path, you don't go left and right ... it's like an inner struggle on how much you could be resistant" (P4).

\subsection{Transcendence}

From the participants' perspective, connectedness with God means transcendence, which is essential for spiritual health. Transcendence is on a spectrum and reaching the "climax" of this relationship, which is absolute transcendence, could not be imagined for all. The participants described this transcendent relationship with God as a continuous movement and a dynamic process, which changes and grows over time. Moreover, transcendence would change and develop with life events:

"Experience, problems, events, or threats that make you think ... when I say God! Something has happened to me, please save me and I'll be your servant. You know... something like that. Or a rare or special event ..." (P9).

One of the manifestations of this transcendent connection was nascence and flourishment defined as trying to "bring one's potentials to fruition" and to use these capabilities for helping oneself and others. Therefore, it occurs with creative activities, continuous learning and teaching, and beneficial activities for others. In this regard, one of the participants stated:

"... He (a person who is spiritually healthy) is beneficial to other humans... He puts aside his selfishness and creates something ... He sacrifices himself"'(P6).

Purpose seeking and wisdom thinking

Another theme was the factor leading to achievement of the ultimate goal and becoming purposeful. A Muslim knows the purpose of creation and existence beyond the material and worldly affaires. This worldview creates the belief that any behavior or action in this world should not be purposeless and ineffective, because any behavior focused on the ultimate goal will be adorable and responded with spiritual and divine rewards. In this regard, a participant mentioned:

"I believe, as a Muslim, ... a man comes to this world from somewhere, he has something to do and somewhere to go. His destination and goals are not here" (P4).

According to the participants' opinions, the true meaning of life would reveal following difficult problems and life events, such as illnesses and loss of loved ones, fostering individuals to consider divine wisdom. Without acceptance of a meaningful life, humans would not experience peace and security, will not be self-fulfilled, and will not enjoy life. This kind of perspective is associated with hope for the future.

"A man who believes in God won't be afraid of anything ... of difficulties. He will consider everything as divine wisdom" (P8).

\subsection{Faith}

Another theme was faith, which was considered to be the result of reciprocal relationships by the participants. This attribute has been explained in internal and external aspects. The external aspect of faith is manifested in religious behaviors and rituals and even spiritual rites, such as art exhibitions. Besides, personal and group worship and prayer reveal the understanding of greatness, immensity, and adorability of the Creator. This was considered by the participants as one of the most obvious components of spiritual health: "Religion is a way to achieve spiritual health, I believe" (P6).

The inner aspect of faith involves inner beliefs based on individuals' worldviews and value system. In case humans match their lifestyles with their value systems, they can achieve bliss and transcendence. In this regard, one of the participants stated:

"A value and belief system is at the top of human existence acting as a filter ... which screens everything and determines what is good and what is bad. Everyone should have a comprehensive worldview that persuades the mind and satisfies the heart" (P11).

\section{Discussion}

Reviewing Iranian Muslim adults' experiences about spiritual health indicated that spiritual health is a complex, multidimensional, and individual concept. According to the results, the significant components of spiritual health were harmonious reciprocal connectedness, moderation, spiritual striving, transcendence, purpose seeking and wisdom thinking, and faith. This study revealed new dimensions of this concept in the Iranian Islamic context.

In this study, all the participants emphasized the unique role of reciprocal relationship with God in the development and promotion of spiritual health. Several studies have also shown that multidimensional relationships between individuals and God, themselves, others, and nature were one of the most important components of spiritual health (50). Other studies also reported that the sense of God's presence was accompanied by peace, hope, and promotion of inner strength $(51,52)$. 
Moreover, relationship with God is the way to reach transcendence, which has been known as one of the attributes of spiritual health in various texts (53-56). Transcendence has been also defined as the ability to see beyond the self-boundaries, environment, and current limitations (56) through developing inner self via introspective activities and developing outer self through relationships with others (57). Such definitions of transcendence imply that transcendence, in addition to relationship with God, implicitly refers to relationship with oneself and introspection as well as to faith and religion, which were other the attributes of spiritual health in the present study. However, relationships would not form spiritual health solely and separately; rather, spiritual health is the result of the interaction among these relationships (58). This means that a sacred relationship with God, the origin of the universe and human existence, would support the recognition of self, and vice versa. In other words, attention to oneself would be a way to access the dominant spirit of the universe.

Moreover, recognizing and having a relationship with the Great Power and the supernatural world leads to understanding the greatness of the world and nature (59). In return, contemplation and thinking about the universe would create awe and wonder, which could result in connectedness with the Creator (60). On the other hand, humans' potentials might be developed and actualized only through interaction with the social environment. Indeed, the good sense of peace originating from spiritual health will shape just in the shade of connecting with family, friends, co-workers, and other individuals (29). In fact, this relationship arises from self-identity and inner self as well as from connectedness with God.

Establishment of moderation in life and communications mentioned by the participants was one of the novel results of this study. Human being is a multi-dimensional existence (61) and, consequently, addressing merely one of these aspects will disturb his balance and peacefulness (46), eventually resulting in deviation from the path of spiritual health. This belief stems from Quran-Islamic teachings of Muslims and Islamic holistic view that has considered all aspects of human existence (33). Accordingly, "intemperance and negligence" in every behavior or human existence aspect is considered to be obscene by Islam. The Holy Quran has also called Islamic nation as a "moderate nation" and has said: “(Qura'n, Sura 2: AlBaqaara): And thus, we have made you a moderate [just] nation". Moreover, according to the hadith of the Holy Prophet of Islam, Prophet Muhammad (PBUH), "The best affairs are the moderate ones" (62).

Thinking and spiritual striving was another novel result of the current study. It seems that individuals achieve spiritual understanding by using reflection and introspection. In addition, they ultimately achieve spiritual selfawareness through an inner journey towards transcendence and finding meaning and purpose in life accompanied by spiritual striving, eventually leading them toward spiritual health (63). Review of the literature related to spiritual health did not reveal spiritual striving as an attribute. However, the importance of striving and abstinence in achieving and maintaining spiritual health has been stated in Islamic texts $(29,59)$. In many verses of the Holy Quran, the use of reasoning, contemplation, and reflection has been emphasized through phrases, such as "Will ye not understand? ... Perchance ye may understand".

Purpose-seeking and wisdom, which were among the main components of spiritual health in the present study, have also been mentioned in the literature (64-68). Understanding the purpose of life and creation was explained by the participants as a purposeful human behavior and belief in the existence of a destination beyond the material world and towards a divine ultimate. On the other hand, the meaning of life is the main core of many belief systems, and religions have explicitly referred to the need for searching and maintaining meaning in life (69). Researchers have also disclosed spiritual health as a factor for answering questions about the meaning of life.

Relationship with God and his creations is manifested through features, including faith. Faith has been defined as trust in and dependence on another being that gives life meaning and value (14). Faith or religious tendency, which was one of the basic components of spiritual health in the current study, can be classified into internal and external categories. The faith in searching for the underlying values of realities will raise intrinsic religiosity. Such individuals look for meaning and purpose in life and will attain internalized understanding of connectedness with the supernatural universe and others through faith (70). On the contrary, external religion refers to a surface and raw understanding that is mostly self-serving (71).

Iran has a religious society where religious beliefs are highly prominent and are closely associated with spiritual health. These two concepts are so intertwined that their separation is not possible. Other studies have also confirmed the fact that in Muslim life, religious beliefs are merged with culture and lifestyle and spirituality and religion are not separate $(33,72)$.

The results of the present study indicated reciprocal interactions among different components of spiritual health, such as faith, transcendence, meaning and purpose, wisdom, and spiritual striving. For example, faith leads to meaning and purpose, and meaning and purpose guide individuals to transcendence. Such complex rela- 
tionships point out the need for performing grounded studies on the concept of spiritual health. The researchers also suggest considering and honoring centuries of philosophical thinking and theological foundations for spiritual concepts and conceptualizations.

Although the results of this study were remarkable and noble, there were certain limitations. One of the limitations of this study was the complex and abstract nature of the concept of spiritual health that along with overlapping with concepts such as spirituality and spiritual wellbeing, might have led to misinterpretation. Experience and subjectivity of the researcher might have also affected the study findings, which is considered to be a limitation in all kinds of qualitative studies. It should also be noted that this study was performed in the Iranian Islamic context. Hence, this construction cannot be presumed to be meaningful for all cultures, because spiritual health should be considered based on cultural and individual differences. Accordingly, this concept is recommended to be evaluated from the perspective of different cultural communities.

\subsection{Conclusions}

In this study, spiritual health was described through the following themes: harmonious reciprocal connectedness, moderation, spiritual striving, transcendence, purpose seeking and wisdom, and faith. These attributes have intertwined connections and can affect each other. These critical characteristics should be taken into consideration in the definition of health. Since health has been considered as a dynamic process of achieving higher levels of well-being in each of the four dimensions of human existence, the holistic approach could be an appropriate strategy for healthcare providers, especially for nurses, to address all aspects of human existence. They can use this approach to identify spiritual health aspects and attributes and to try to incorporate them into caring and health promotion.

Ignoring the spiritual dimension of health would result in deprivation from the leverage needed to empower individuals and communities to achieve the highest levels of physical, psychological, and social health. The nursing profession, as a profession aiming at providing health and well-being, could address holistic well-being as its greatest professional goal. This spiritual activity through divine connection would eventually result in spiritual health promotion as a healthy behavior.

\section{Acknowledgments}

This manuscript was a part of the Ph.D. dissertation written by Azita Jaberi and financially supported by the
Vice-Chancellor for Research Affairs of Shiraz University of Medical Sciences (No. 93-7216). Hereby, the authors would like to thank Ms. A. Keivanshekouh at the Research Improvement Center of Shiraz University of Medical Sciences for improving the use of English in the manuscript.

\section{Footnotes}

Authors' Contribution: Conception and design of the study: Marzieh Momennasab; analysis and interpretation of the data and final approval of the version to be submitted: Marzieh Momennasab, Azita Jaberi, Shahrzad Yektatalab, Abbas Ebadi, and Mohammad Ali Cheraghi; drafting the article: Marzieh Momennasab, Azita Jaberi; revising the article: Marzieh Momennasab, Azita Jaberi, Shahrzad Yektatalab, and Mohammad Ali Cheraghi.

Conflict of Interests: It is not declared by the authors.

Ethical Approval: This study was approved by the Ethics Committee of Shiraz University of Medical Sciences (code: 93-7216).

Funding/Support: The authors disclosed receipt of the financial support from the Vice-Chancellor for Research Affairs of Shiraz University of Medical Sciences, Iran.

\section{References}

1. Tiew LH, Creedy DK, Chan MF. Student nurses' perspectives of spirituality and spiritual care. Nurse Educ Today. 2013;33(6):574-9. doi: 10.1016/j.nedt.2012.06.007. [PubMed: 22789873].

2. Osman JD, Russell RD. The spiritual aspects of health. J Sch Health. 1979;49(6):359. doi: 10.1111/j.1746-1561.1979.tb07733.x. [PubMed: 257128].

3. Anonymous. Spiritual health is important, say our readers. WHO Chron. 1979;33:29-30.

4. Hungelmann J, Kenkel-Rossi E, Klassen L, Stollenwerk RM. Spiritual well-being in older adults: Harmonious interconnectedness. J Relig Health. 1985;24(2):147-53. doi: 10.1007/BF01532258. [PubMed: 24306074].

5. Scales PC, Syvertsen AK, Benson PL, Roehlkepartain EC, Sesma A. Relation of spiritual development to youth health and well-being: Evidence from a global study. Handbook of Child Well-Being. Springer; 2014. p. 1101-35. doi: 10.1007/978-90-481-9063-8_41.

6. Smith J, McSherry W. Spirituality and child development: A concept analysis. J Adv Nurs. 2004;45(3):307-15. doi: 10.1046/j.13652648.2003.02891.x. [PubMed: 14720248].

7. Selman L, Speck P, Gysels M, Agupio G, Dinat N, Downing J, et al.'Peace' and 'life worthwhile' as measures of spiritual well-being in African palliative care: A mixed-methods study. Health Qual Life Outcomes. 2013;11:94. doi: 10.1186/1477-7525-11-94. [PubMed: 23758738]. [PubMed Central: РMC3687576].

8. Sinclair S, Pereira J, Raffin S. A thematic review of the spirituality literature within palliative care. J Palliat Med. 2006;9(2):464-79. doi: 10.1089/jpm.2006.9.464. [PubMed: 16629575].

9. Powell LH, Shahabi L, Thoresen CE. Religion and spirituality. Linkages to physical health. Am Psychol. 2003;58(1):36-52. doi: 10.1037/0003066x.58.1.36. [PubMed: 12674817]. 
10. Boswell GH, Kahana E, Dilworth-Anderson P. Spirituality and healthy lifestyle behaviors: Stress counter-balancing effects on the well-being of older adults. J Relig Health. 2006;45(4):587-602. doi: 10.1007/s10943006-9060-7.

11. King PE, Benson PL, Wagener L. Religion, spirituality, and children's physical health. In: Oman D, Thoresen CE, editors. The handbook of spiritual development in childhood and adolescence. Sage publications; 2006. p. 399-415.

12. Chapman LS. Developing a useful perspective on spiritual health: Well-being, spiritual potential and the search for meaning. Am J Health Promot. 1987;1(3):31-9. doi: 10.4278/0890-1171-1.3.31. [PubMed: 22208296].

13. Burkhardt MA. Becoming and connecting: Elements of spirituality for women. Holist Nurs Pract. 1994;8(4):12-21. doi: 10.1097/00004650199407000-00004. [PubMed: 8027193].

14. Fowler J. Stages of faith: The psychology of human development and the quest for meaning. New York: Harper \& Row; 1981.

15. Zinnbauer BJ, Pargament KI, Scott AB. The emerging meanings of religiousness and spirituality: Problems and prospects. J Pers. 1999;67(6):889-919. doi:10.1111/1467-6494.00077.

16. Presidency of the IRI Plan and Budget Organization. National population and housing statistics. Tehran, Iran; 2015.

17. Erikson E. Childhood and society. New York: W.W. Norton \& Co; 1950.

18. Jafari N, Zamani A, Farajzadegan Z, Bahrami F, Emami H, Loghmani A. The effect of spiritual therapy for improving the quality of life of women with breast cancer: A randomized controlled trial. Psychol Health Med. 2013;18(1):56-69. doi: 10.1080/13548506.2012.679738. [PubMed: 22533516].

19. Farahaninia M, Jadidi A, Janmohammadi S, Haghani H. Relationship between spiritual well-being and quality of life among elderly peopleresiding in Kahrizak Senior House. Eur Psychiatr. 2013;28:1. doi: 10.1016/s0924-9338(13)77267-5.

20. Sturmberg J. How to teach holistic care-meeting the challenge of complexity in clinical practice. Educ Health (Abingdon). 2005;18(2):236-45. doi: 10.1080/13576280500154062. [PubMed: 16009617].

21. Potter PA, Perry AG, Stockert P, Hall A. Fundamentals of nursing. Elsevier Health Sciences; 2013.

22. Taylor C, Lillis C, LeMone P, Lynn PA. Fundamentals of nursing: The art and science of nursing care. Lippincott Philadelphia; 2001.

23. Vader JP. Spiritual health: The next frontier. Eur J Public Health. 2006;16(5):457. doi: 10.1093/eurpub/ckl234. [PubMed: 17012297].

24. Burkhart L, Schmidt L, Hogan N. Development and psychometric testing of the Spiritual Care Inventory instrument. J Adv Nurs. 2011;67(11):2463-72. doi: 10.1111/j.1365-2648.2011.05654.x. [PubMed: 21517939].

25. Ross L. Commentary on Paley J(2008) Spirituality and secularization: Nursing and the sociology of religion. Journal of Clinical Nursing 17, 175-186. J Clin Nurs. 2008;17(20):2795-8. discussion 2799-800. doi: 10.1111/j.1365-2702.2008.02401.x. [PubMed: 18808651].

26. Lim JW, Yi J. The effects of religiosity, spirituality, and social support on quality of life: A comparison between Korean American and Korean breast and gynecologic cancer survivors. Oncol Nurs Forum. 2009;36(6):699-708. doi: 10.1188/09.0NF.699-708. [PubMed: 19887358].

27. Yang KP, Wu XJ. Spiritual intelligence of nurses in two Chinese social systems: A cross-sectional comparison study. J Nurs Res. 2009;17(3):189-98. doi: 10.1097/JNR.0b013e3181b2556c. [PubMed: 19738447].

28. van Dierendonck D, Rodriguez-Carvajal R, Moreno-Jimenez B, Dijkstra MTM. Goal integration and well-being: Selfregulation through inner researches in the Netherlands and Spain. J Cross Cult Psychol. 2009;40(5):746-60. doi: 10.1177/0022022109338622.

29. Mousavimughaddam $S$. [Healthy man and its role in the spiritual health and mental health from the viewpoints of rene descartes and Allamah Tabatabaei based on the interpretative attitude of Almizan].
Sci J Zanjan Univ Med Sci. 2013;22(90):33-44. Persian.

30. Moosavi-Khomeyni R. [40 Hadis]. Qom: Moaseseye Tanzim va Nashre Asare Emam Khomeyni; 2004. Persian.

31. Motahari M. [Introduction to monotheistic aspects]. Tehran: Sadra; 2003. Persian.

32. Marzband R, Zakavi AA. [Indicators of spiritual health based on Quran perspective]. Iran J Med Ethics. 2012;6(20):69-99. Persian.

33. Rassool GH. The crescent and Islam: Healing, nursing and the spiritual dimension. Some considerations towards an understanding of the Islamic perspectives on caring.JAdv Nurs. 2000;32(6):1476-84. doi: 10.1046/j.1365-2648.2000.01614.x. [PubMed: 11136416].

34. Bin-Abbas M. The soul according to Ibn-Sina. 2014. Available from: http: //www.quranichealing.net/chp2_p.php?id=16.

35. Torskenaes KB, Baldacchino DR, Kalfoss M, Baldacchino T, Borg J, Falzon M, et al. Nurses' and caregivers' definition of spirituality from the Christian perspective: A comparative study between Malta and Norway. J Nurs Manag. 2015;23(1):39-53. doi: 10.1111/jonm.12080. [PubMed: 23822866]

36. Hedstrom M. The construction of "Judeo-Christian" spirituality in postwar America. 2013. Available from: http://citation.allacademic.com/meta/ p105728_index.html.

37. Conner NE, Eller LS. Spiritual perspectives, needs and nursing interventions of Christian African-Americans. J Adv Nurs. 2004;46(6):62432. doi: 10.1111/j.1365-2648.2004.03053.x. [PubMed: 15154903].

38. Laird LD, de Marrais J, Barnes LL. Portraying Islam and Muslims in MEDLINE: A content analysis. Soc Sci Med. 2007;65(12):2425-39. doi: 10.1016/j.socscimed.2007.07.029. [PubMed: 17767988].

39. Iranmanesh S, Tirgari B, Cheraghi MA. Developing and testing a spiritual care questionnaire in the Iranian context. $J$ Relig Health. 2012;51(4):1104-16. doi: 10.1007/s10943-011-9458-8. [PubMed: 21258864].

40. Khorami Markani A, Yaghmaei F, Khodayari Fard M. Spirituality as experienced by Muslim oncology nurses in Iran. Br J Nurs. 2013;22(Sup2):S22-8.

41. European Values Study Group; World Values Surveys Association. European and World Values Surveys Four-wave Integrated Data File. 2000.

42. Ellison CW. Spiritual well-being: Conceptualization and measurement. $J$ Psychol Theol. 1983;11(4):330-8. doi: 10.1177/009164718301100406.

43. Ross L. Spiritual care in nursing: An overview of the research to date. J Clin Nurs. 2006;15(7):852-62. doi: 10.1111/j.1365-2702.2006.01617.x. [PubMed: 16879378].

44. Fisher J. Spiritual health: Its nature and place in the school curriculum [dissertation]. Melbourne, Ausralia: The University of Melbourne; 1998.

45. Moberg D. Subjective measures of spiritual well being: Review of religious research. Relig Res Assoc. 1984;25(4):351-64. doi: 10.2307/3511368.

46. Baldacchino D, Draper P. Spiritual coping strategies: A review of the nursing research literature. J Adv Nurs. 2001;34(6):833-41. doi 10.1046/j.1365-2648.2001.01814.x. [PubMed: 11422554].

47. Creswell JW, Poth CN. Qualitative inquiry and research design: Choosing among five approaches. Sage publications; 2016

48. Graneheim UH, Lundman B. Qualitative content analysis in nursing research: Concepts, procedures and measures to achieve trustworthiness. Nurse Educ Today. 2004;24(2):105-12. doi: 10.1016/j.nedt.2003.10.001. [PubMed:14769454].

49. Speziale HS, Streubert HJ, Carpenter DR. Qualitative research in nursing: Advancing the humanistic imperative. Wolters Kluwer Health, Lippincott Williams \& Wilkins; 2011.

50. Fisher J. Development and application of a spiritual well-being questionnaire called SHALOM. Religions. 2010;1(1):105-21. doi: 10.3390/rel1010105.

51. Walton J. Spirituality of patients recovering from an acute myocardial infarction. A grounded theory study.J Holist Nurs.1999;17(1):34-53. doi: 10.1177/089801019901700104. [PubMed: 10373841]. 
52. Bingham V. The recovery experience for persons with a myocardial in farction and their spouses/partners [dissertation]. The University of Alabama; 2007.

53. Reed PG. An emerging paradigm for the investigation of spirituality in nursing. Res Nurs Health. 1992;15(5):349-57. doi: 10.1002/nur.4770150505. [PubMed:1529119].

54. Chiu L, Emblen JD, Van Hofwegen L, Sawatzky R, Meyerhoff H. An integrative review of the concept of spirituality in the health sciences. West J Nurs Res. 2004;26(4):405-28. doi: 10.1177/0193945904263411. [PubMed: 15155026].

55. Edwards A, Pang N, Shiu V, Chan C. The understanding of spirituality and the potential role of spiritual care in end-of-life and palliative care: A meta-study of qualitative research. Palliat Med.2010;24(8):75370. doi: 10.1177/0269216310375860. [PubMed: 20659977].

56. Weathers E, McCarthy G, Coffey A. Concept analysis of spirituality: An evolutionary approach. Nurs Forum. 2016;51(2):79-96. doi: 10.1111/nuf.12128. [PubMed: 25644366].

57. Meraviglia MG. Critical analysis of spirituality and its empirical indicators. Prayer and meaning in life. J Holist Nurs. 1999;17(1):18-33. doi: 10.1177/089801019901700103. [PubMed: 10373840].

58. Bellingham R, Cohen B, Jones T, Spaniol le R. Connectedness: Some skills for spiritual health. Am J Health Promot. 1989;4(1):18-31. doi: 10.4278/0890-1171-4.1.18. [PubMed: 22204354].

59. Mousavimughadam SR, Delpisheh A. Concept of spiritual health in Descartes' and Tabatabaei's perspectives. J Stud Relig Ideologies. 2012;11(32):93-108.

60. Wright M. Hospice care and models of spirituality. Eur J Palliat Care. 2004;11(2):75-8.

61. Mason-Whitehead E, McIntosh A, Bryan A, Mason T. Key concepts in nursing. Los Angeles: Sage; 2008.

62. Al-Majlisi M. Bihar al-anwar. Beirut: Al-Wafa; 1983.
63. Pesut B. Spirituality and spiritual care in nursing fundamentals textbooks. J Nurs Educ. 2008;47(4):167-73. doi: 10.3928/0148483420080401-05. [PubMed: 18468293].

64. Barker SL, Floersch JE. Practitioners' understandings of spirituality: Implications for social work education. J Soc Work Educ. 2013;46(3):357-70. doi: 10.5175/jswe.2010.200900033.

65. Buck HG, Meghani SH. Spiritual expressions of African Americans and Whites in cancer pain. J Holist Nurs. 2012;30(2):107-16. doi: 10.1177/0898010111423420. [PubMed: 22024953]. [PubMed Central: PMC3887517].

66. Tanyi RA. Towards clarification of the meaning of spirituality. J Adv Nurs. 2002;39(5):500-9. doi: 10.1046/j.1365-2648.2002.02315.x. [PubMed: 12175360].

67. Bensley RJ. Defining spiritual health: A review of the literature. $J$ Health Educ. 1991;22(5):287-90. doi:10.1080/10556699.1991.10614636.

68. Benzein E, Norberg A, Saveman BI. Hope: future imagined reality. The meaning of hope as described by a group of healthy Pentecostalists. J Adv Nurs. 1998;28(5):1063-70. doi: 10.1046/j.1365-2648.1998.00820.x. [PubMed: 9840878].

69. Delgado C. A discussion of the concept of spirituality. Nurs Sci Q. 2005;18(2):157-62. doi: 10.1177/0894318405274828. [PubMed: 15802748].

70. Gall TL, Grant K. Spiritual disposition and understanding illness. Pastor Psychol. 2005;53(6):515-33. doi: 10.1007/s11089-005-4818-y.

71. Denney R. Posttraumatic spiritual growth: A phenomenological study of cancer survivors [dissertation]. The University of Southern Mississipi; 2009.

72. Karimollahi M, Abedi HA, Yousefy A. Spiritual needs as experienced by Muslim patients in Iran: A qualitative study. Ann Gen Psychiatr. 2008;7(S1). doi: 10.1186/1744-859x-7-s1-s147. 